\title{
Impact of Continuous Cropping on the Diurnal Range of Dew Point Temperature during the Foliar Expansion Period of Annual Crops on the Canadian Prairies
}

\author{
Bharat M. Shrestha, ${ }^{1,2}$ Richard L. Raddatz, ${ }^{3}$ Raymond L. Desjardins, ${ }^{1}$ and Devon E. Worth ${ }^{1}$ \\ ${ }^{1}$ Ottawa Research and Development Centre, 960 Carling Avenue, K. W. Neatby Building, Ottawa, ON, Canada K1A 0C6 \\ ${ }^{2}$ Ontario Forest Research Institute, Ontario Ministry of Natural Resources and Forestry, 1235 Queen Street East, \\ Sault Ste. Marie, ON, Canada P6A 2E5 \\ ${ }^{3}$ Centre for Earth Observation Science, University of Manitoba, Winnipeg, MB, Canada R3T 2N2
}

Correspondence should be addressed to Raymond L. Desjardins; ray.desjardins@agr.gc.ca

Received 27 June 2015; Revised 5 November 2015; Accepted 8 November 2015

Academic Editor: Li-Liang Ren

Copyright (C) 2016 Bharat M. Shrestha et al. This is an open access article distributed under the Creative Commons Attribution License, which permits unrestricted use, distribution, and reproduction in any medium, provided the original work is properly cited.

\begin{abstract}
It is important to increase our knowledge of the role of land use in changing the regional climate. This study asked, "Has the increase in continuous cropping over the past 50 years on the Canadian Prairies influenced the daily mean and range of morning dew point temperatures $\left(T_{d}\right)$ during the foliar expansion period (from mid-June to mid-July) of annual field crops?" We found that there has been a general increase in the decadal average of mean daily $T_{d}$ and in the range of morning $T_{d}$ from the 1960s to the 2000s. The increase in the observed range of $T_{d}$ between the daily minimum value, which typically occurs near sunrise, and the late morning peak was found to be related to the increase in annual crop acreage and consequent decrease in summerfallow area. The relationship was more significant in the subhumid climatic zone than in the semiarid climatic zone, and it was influenced by whether the region was experiencing either wet, normal, or dry conditions.
\end{abstract}

\section{Introduction}

Land use and land use change can significantly impact regional climates through their effects on the surface energy and water budgets [1-4]. Raddatz [2] reviewed the influence of agriculture on regional climates and concluded that agriculture, by altering the physiological and physical properties of the land cover, impacts near surface weather elements and the regional hydrological cycle including the occurrence and intensity of moist deep convection. Several studies have examined the influence of agriculture on surface dew point temperature $\left(T_{d}\right)$. For example, Changnon et al. [5] showed that agriculture enhanced daily evapotranspiration (ET) and increased the mean daily dew point temperature $\left(T_{d \text {-mean }}\right)$ during Chicago heat waves. Raddatz and Hanesiak [6] reported that about $80 \%$ of summer precipitation events on the Canadian Prairies include convective rainfall whose probability-of-occurrence is enhanced by the impact of ET from annual field crops on $T_{d}$ and subsequently on convective available potential energy (CAPE).

Summer fallowing is a soil moisture conservation practice which keeps cropland purposely out of production during a growing season so that the crop grown in the following year will be less dependent on growing season precipitation. The practice of summer fallowing has been common on the Canadian Prairies since the beginning of the 20th century. Its use increased until 1961; the total acreage peaked at 11.4 Mha (25\% of cultivated land). Summerfallow acreage has steadily decreased since 1961, dropping to 2.1 Mha in 2011 [8] as continuous cropping has become more common [9]. Gameda et al. [10] reported a reduction in maximum air temperature $\left(1.7^{\circ} \mathrm{C}\right.$ decade $\left.^{-1}\right)$, diurnal temperature range $\left(1.1^{\circ} \mathrm{C}\right.$ decade $\left.^{-1}\right)$, and solar radiation $\left(1.2 \mathrm{MJ} \mathrm{m}^{-2}\right.$ decade $\left.^{-1}\right)$, as well as an increase in precipitation $\left(10.3 \mathrm{~mm} \mathrm{decade}^{-1}\right)$ during the foliar expansion period (approximately mid-June to mid-July) associated with the reduction in summerfallow 


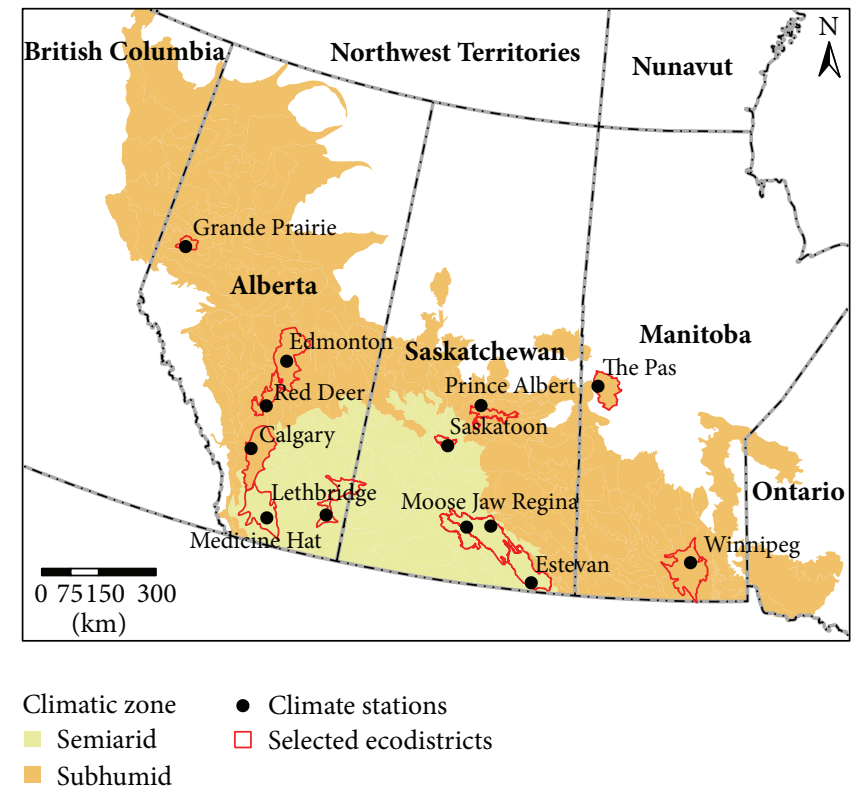

Figure 1: Map of the study area with representative climate stations in the subhumid and semiarid climatic zones. Climatic zones were delineated based on precipitation to potential evapotranspiration $(\mathrm{P} / \mathrm{PE}$ ) ratio (subhumid if $\mathrm{P} / \mathrm{PE} \geq 0.52$, semiarid if $\mathrm{P} / \mathrm{PE}<0.52$ ). Ecodistricts containing a selected climate station are highlighted in red. Land, crop and summerfallow area for these ecodistricts are given in Table 1.

acreage from 1976 to 2001 on the Canadian Prairies. Shrestha et al. [3] confirmed that the conversion from summerfallow to continuous cropping on the Canadian Prairies between 1976 and 2001 increased ET during the foliar expansion period for annual field crops and likely increased the CAPE and thereby the probability of moist deep convection during this period.

An analysis of the relationship between changing agricultural land use and $T_{d}$ trends in the agricultural region of the Canadian Prairies is lacking. Therefore, a study was carried out to determine if there has been a widespread change in the daily mean and morning $T_{d}$ range $\left(T_{d r}\right)$ in the Canadian Prairies during the foliar expansion period (DOY 165-195) of annual field crops when daily ET is at its seasonal maximum and to determine if this change is correlated with the reduction of the summerfallow acreage and the increase in the acreage of annual crops. Hanesiak et al. [11] analyzed the diurnal cycle of precipitable water vapour in the southeastern Prairies and found that its diurnal cycle was controlled by the daily ET cycle and the timing of moist deep convection. Decadal average foliar expansion period values were used in the assessment of daily $T_{d \text {-mean }}$. Averaging minimizes the influence of moisture advection by multiday synoptic events and maximizes the influence of the daily ET on $T_{d}$ [11]. The decadal diurnal $T_{d}$ cycle was examined for the rural or urban signature [12]. The annual foliar expansion period mean daily $T_{d r}$ was calculated to investigate its relationship with summerfallow acreages. The summer seasons in the ecoregions were grouped into normal, wet, and dry to account for these contrasting climatological conditions on $T_{d}$ and $T_{d r}$ during the period covered by this study.

\section{Material and Methods}

2.1. Study Area and Land Use Data. The study area was the subhumid and semiarid climatic zones of the Canadian Prairie Provinces (Alberta, Manitoba and Saskatchewan, Figure 1) which correspond to the "moist cool temperate" and "dry cool temperate" climatic zones, respectively, as defined by the Intergovernmental Panel on Climate Change [13]. The agricultural land use database at the ecodistrict (ED) scale was employed as it includes the area of annual and perennial crops, grasslands, and summerfallow for the Agricultural Census years of 1961, 1971, 1981, 1986, 1991, 1996, 2001, and 2006 [8]. An ED is a subregion of a climatic zone where similar physical geography, soils, and climate produce similar vegetation [14]. The census year data on cropland and summerfallow area in each ED were interpolated for each year and calculated as percentage of total land area of the respective $\mathrm{ED}$. We selected $\mathrm{EDs}$ with a wide range of land use change (conversion of summerfallow to annual cropping) between the 1960 s and the 2000s. The total area, crop area, and summerfallow area for 1961 (our start year) and 2006 (our final year) in both subhumid and semiarid climatic zones are listed in Table 1. Weather stations were selected representing EDs in both climatic zones and the latitudinal difference between stations was kept to a minimum to facilitate comparability between EDs in subhumid and semiarid climatic zones (Figure 1, Table 1). The subhumid climatic zone of the Canadian Prairies contains mainly gray, dark gray, and black soils and the semiarid climatic zone contains mainly dark brown and brown soils [15]. The recent reduction of summerfallow acreage has been greater in the 


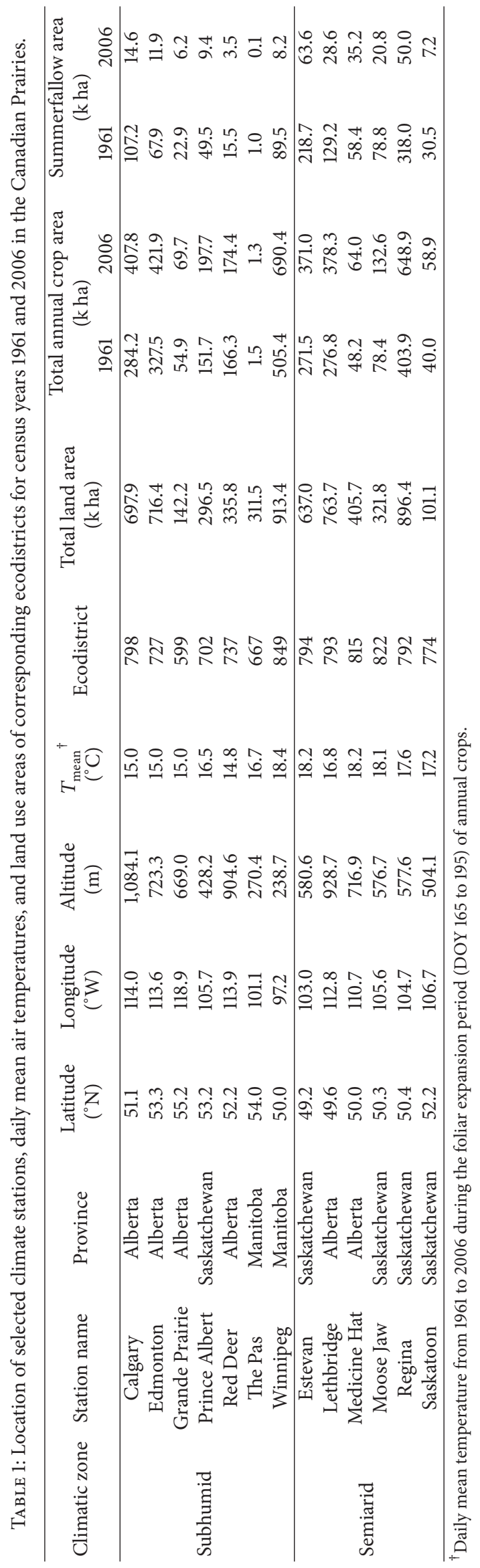


semiarid climatic zone than in the subhumid climatic zone (Table 1).

Crop maturity varies with seeding date, which varies from year to year, and with the growing season's weather conditions [16]. Since the seeding dates were not available, we assumed that the impact of the interannual variability of the foliar expansion period on the $T_{d \text {-mean }}$ for the midJune to mid-July period and on its diurnal cycle during this period would be minimized by examining decadal average values. The decadal average diurnal $T_{d}$ cycles were calculated for representative weather stations in EDs with minimal land use change (e.g., The Pas, Red Deer, and Grande Prairie) and compared with the decadal average diurnal $T_{d}$ cycles for stations in EDs that had larger increases in annual crop acreage (e.g., Calgary, Regina, and Estevan) (Table 1). The relationship between the annual foliar expansion period $T_{d r}$ and summerfallow area, interpolated from census year data, was examined to quantify the effect of land use change. This study used the same temperature and humidity data that Betts et al. [17-21] used to enhance the understanding of the landatmosphere relationship in the Canadian Prairies.

2.2. Weather Data and Analysis. Hourly $T_{d}$, hourly precipitation events, and daily precipitation amounts for the selected weather stations (Table 1) were extracted from Environment Canada's climate data archive. To be selected, a weather station had to have 50 years of data covering the period from the 1960s through the 2000s.

Ventilated psychrometers, used to measure $T_{d}$ in the 1950 s and 1960s, were replaced by dewcels in the early 1970s at most weather stations in Canada and by the Automatic Weather Observing Systems (AWOS) in the 1990s. Vincent et al. [22] tested the $T_{d}$ time-series from weather stations across Canada for inhomogeneity associated with instrument change. No inhomogeneity associated with the instrument change was detected at the stations selected for this study.

Urbanization could have also affected $T_{d}$ values [23] over the study period. At each weather station, we examined the average diurnal cycle of hourly $T_{d}$ values for each decade from the 1960s onward for the mid-June to mid-July period $(\approx$ DOY, 165-195) when crops transpire at their highest rate [10] and checked for the presence or absence of a double peaked diurnal cycle; the latter is indicative of a rural setting [12].

While daily rainfall amounts were readily available, hourly amounts were not. However, hourly precipitation events are available which have been classified using a scale from 0 to 3. No precipitation was coded as "0," light precipitation as " 1 ," moderate precipitation as " 2 ," and heavy precipitation as " 3 " [24]. The hourly frequency and the average diurnal cycle of this occurrence/intensity code were determined for the foliar expansion period. Daily rainfall amounts were used to determine the total antecedent precipitation from April 1 (the approximate start of the growing season, DOY 91) to July 15 (DOY 195). These rainfall parameters were analyzed to explore their influence on the decadal $T_{d \text {-mean }}$ and the decadal average diurnal $T_{d}$ cycle. Each decade was classified as normal, dry, or wet based on the average accumulated antecedent precipitation compared to the 30-year normal (1961-1990). If a decade's average antecedent precipitation was within one standard error (SE) of the normal, the decade was classified as "normal"; if it was less than normal by more than one SE, it was classified as "dry"; if it was greater than one SE above normal, it was classified as "wet." Similarly, each year from 1961 to 2006 was classified as either "dry," "normal," or "wet" year using one standard deviation (SD) as the metric [25].

$T_{d r}$ was defined as the difference between the daily minimum $T_{d}\left(T_{d-\min }\right)$, which typically occurred near sunrise, and the maximum $T_{d}\left(T_{d-\max }\right)$ which typically occurred in the late morning [12]. Average $T_{d r}$ values for the foliar expansion period were then calculated for each year from 1961 to 2006. The relationship between $T_{d r}$ during the foliar expansion period and the percentage of land under summerfallow in each ecodistrict was assessed for each year from 1961 to 2006.

\section{Results and Discussion}

3.1. Temporal Trends of Dew Point Temperature. Decadal averages and $\mathrm{SD}$ of the $T_{d}$ during the foliar expansion period are listed in Table 2. Most of the weather stations experienced dry conditions in the 1960s and the 1980s while the 1970s and 1990s were wet decades (Table 2), though this varied from station to station. Dry conditions were associated with a lower decadal $T_{d \text {-mean }}$ during the foliar expansion period, and the opposite was also true for wet conditions showing that decadal $T_{d \text {-mean }}$ varied with the precipitation regime (Table 2).

While the trend in $T_{d \text {-mean }}$ varied from station to station, all stations had a positive trend from the 1960s to the 2000s. Trends ranged from 0.01 to $0.47^{\circ} \mathrm{C}_{\text {decade }}{ }^{-1}$ (Table 2). Positive trends in $T_{d \text {-mean }}$ were found for stations within EDs with minimal or no change in annual crop acreage as well as for EDs with a large increase in annual crop acreage. However, the upward trend was negligible in the former EDs than in the latter EDs. For example, Grande Prairie, representing ED 559 with a minimal change in annual crop acreage, had an incremental increase in $T_{d \text {-mean }}$ of only $0.01^{\circ} \mathrm{C}_{\text {decade }}{ }^{-1}$, while Winnipeg, a station representing ED 849, with a large increase in annual crop acreage had an incremental increase of $0.42^{\circ} \mathrm{Cdecade}^{-1}$ (Table 2). These results suggest that at least part of the increase in decadal $T_{d \text {-mean }}$ during the foliar expansion period was attributable to the increase in the area of annual field crops and a decrease of the area under summerfallow (Table 1). Furthermore, the variations in $T_{d \text {-mean }}$ associated with a given precipitation regime were larger in the semiarid region compared to the subhumid region (Table 2).

3.2. Decadal Diurnal Cycle of Dew Point Temperatures. The decadal average diurnal cycle of hourly $T_{d}$ values from the 1960s onwards is presented for Winnipeg and Estevan, representing the subhumid and semiarid climatic zones, respectively (Figures 2(a) and 2(b)). These two weather stations are located at approximately the same latitude $\left(\sim 50^{\circ} \mathrm{N}\right)$ but represent two distinct climatic zones (Table 1, Figure 1). The plots illustrate that there is a typical diurnal cycle for $T_{d}$ during the foliar expansion period of annual crops on the Canadian Prairies. On average for each decade, $T_{d}$ decreased 


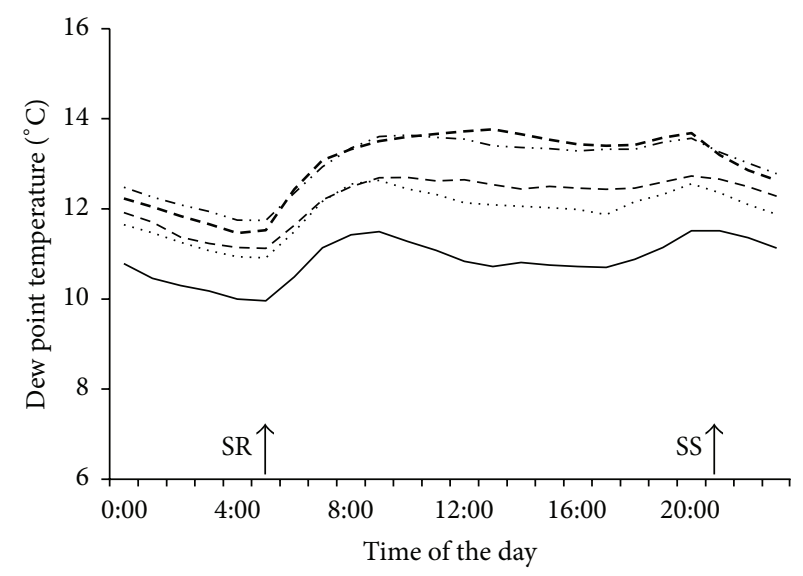

(a) Winnipeg

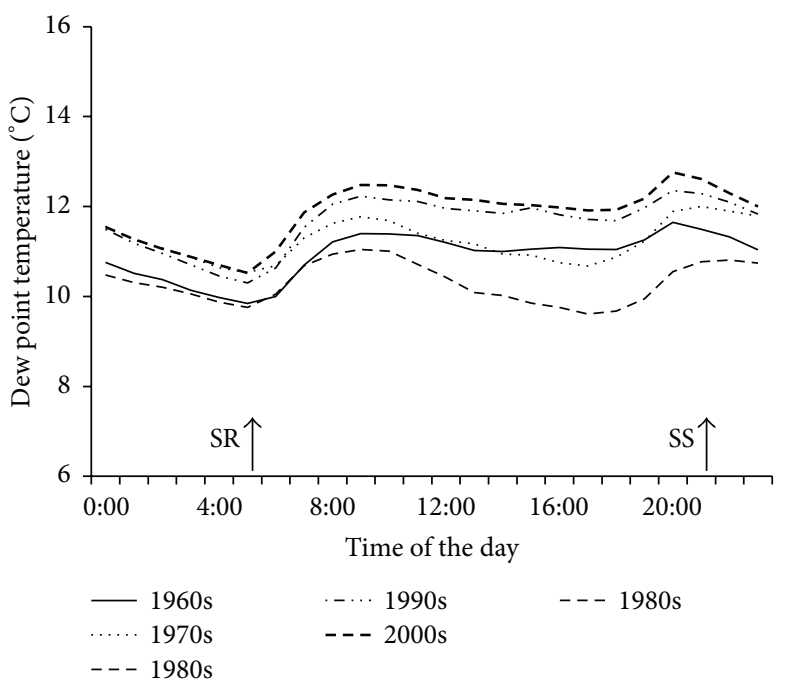

(b) Estevan

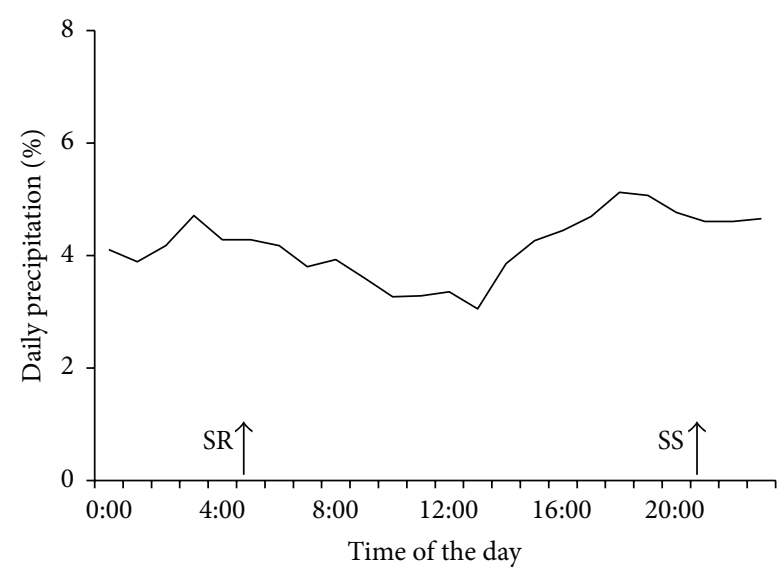

(c) Winnipeg

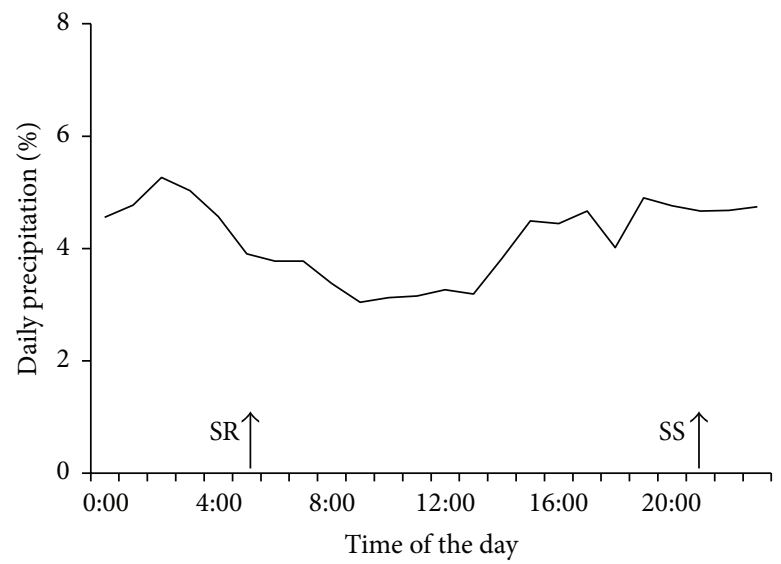

(d) Estevan

FIGURE 2: Decadal average diurnal cycles of dew point temperatures for the average foliar expansion period for annual field crops (DOY 165-195) for (a) Winnipeg (subhumid climatic zone) and for (b) Estevan (semiarid climatic zone). (c) and (d) show the hourly percentage of daily precipitation events for the foliar expansion period for (c) Winnipeg and (d) Estevan. Upward arrows show local standard time (LST) for sunrise (SR) and sunset (SS). The province of Saskatchewan does not follow day light savings time; therefore LST in Estevan was adjusted by adding one hour for comparison with Winnipeg.

during the night reaching a minimum around sunrise (Figures 2(a) and 2(b)). After sunrise, $T_{d}$ increased and reached a maximum in the late morning. After declining for a few hours, $T_{d}$ increased again in late afternoon with a second peak in the evening. This double peaked diurnal $T_{d}$ cycle (Figure 2) is typical of rural sites and confirms that urbanization has had a minimal influence on $T_{d}$ values on the Canadian Prairies [7, 12]. The average diurnal $T_{d}$ cycle can be explained, in part, by the common conceptual model of the atmospheric boundary layer's (ABL's) diurnal cycle (Figure 3). Typically, the ABL responds to the daily heating/cooling cycle. Overnight, an inversion often forms which promotes downward moisture flux (condensation on the surface or dew). This removal of moisture from the ABL gives minimum $T_{d}$ values around sunrise. After sunrise, a mixed layer often develops and along with it a rapid increase in ET occurs. Moisture from an elevated residual layer, a carryover from the previous day's mixed layer, may also be incorporated into the growing mixed layer. These two factors typically lead to a rapid increase in $T_{d}$ which usually reaches a maximum value during the late morning. Through the afternoon, deepening of the mixed layer with entrainment of drier air from the free atmosphere often reduces $T_{d}$ from its late-morning maximum value. The typical second or evening peak in $T_{d}$ can be explained by the high frequency of convective precipitation events at that time of day [11] and from an uncoupling from the surface [18]. The average diurnal cycles of precipitation occurrence/intensity for the decades from the 1960s to the 2000s for Winnipeg and Estevan are presented in Figures 2(c) and 2(d). On average, the highest precipitation occurrence/intensity code occurred in the evening at 20:00 local standard time (LST) (Figures 2(c) and 2(d)), while the evening peak in $T_{d}$ occurred, on average, at around 21:00 LST (Figures 2(a) and 2(b)). This cooccurrence strongly suggests that the evaporation of rain, 
TABLE 2: Rate of change of the average decadal mean daily dew point temperature $\left(T_{d \text {-mean }}\right)$ and decadal averages and standard deviations of dew point temperatures for climate stations representing selected ecodistricts in the Canadian Prairies for the 1960s to the 2000s.

\begin{tabular}{|c|c|c|c|c|c|c|c|}
\hline \multirow[t]{2}{*}{ Climatic zone } & \multirow[t]{2}{*}{ Weather station } & \multirow{2}{*}{$\begin{array}{c}\text { Rate of change } \\
\left({ }^{\circ} \mathrm{C} \text { decade }{ }^{-1}\right) \\
T_{d \text {-mean }} \\
\end{array}$} & \multicolumn{5}{|c|}{$\begin{array}{l}\text { Decadal average and standard deviation of dew } \\
\text { point temperature }\left({ }^{\circ} \mathrm{C}\right)\end{array}$} \\
\hline & & & 1960s & 1970s & 1980 s & 1990 s & 2000 s \\
\hline \multirow{7}{*}{ Subhumid } & Calgary & 0.20 & $6.6 \pm 1.2^{\mathrm{n}}$ & $6.1 \pm 1.6^{\mathrm{n}}$ & $6.4 \pm 1.8^{\mathrm{n}}$ & $7.7 \pm 1.4^{\mathrm{w}}$ & $7.8 \pm 1.4^{\mathrm{w}}$ \\
\hline & Edmonton & 0.10 & $8.3 \pm 1.1^{\mathrm{d}}$ & $9.4 \pm 1.5^{\mathrm{w}}$ & $9.0 \pm 1.5^{\mathrm{w}}$ & $9.4 \pm 1.2^{\mathrm{w}}$ & $8.9 \pm 1.5^{\mathrm{d}}$ \\
\hline & Grande Prairie & 0.01 & $7.2 \pm 1.1^{\mathrm{n}}$ & $7.4 \pm 0.9^{\mathrm{n}}$ & $7.4 \pm 2.0^{\mathrm{n}}$ & $8.5 \pm 1.2^{\mathrm{w}}$ & $7.1 \pm 1.1^{\mathrm{n}}$ \\
\hline & Prince Albert & 0.19 & $9.5 \pm 1.9^{\mathrm{d}}$ & $10.4 \pm 1.2^{\mathrm{w}}$ & $9.5 \pm 0.7^{\mathrm{n}}$ & $9.8 \pm 1.7^{\mathrm{w}}$ & $10.3 \pm 1.3^{\mathrm{n}}$ \\
\hline & Red Deer & 0.06 & $7.9 \pm 0.9^{\mathrm{d}}$ & $7.8 \pm 1.4^{\mathrm{n}}$ & $8.8 \pm 1.5^{\mathrm{n}}$ & $8.5 \pm 1.6^{\mathrm{w}}$ & $8.5 \pm 1.3^{\mathrm{n}}$ \\
\hline & The Pas & 0.06 & $9.6 \pm 2.0^{\mathrm{d}}$ & $10.8 \pm 0.9^{\mathrm{w}}$ & $9.7 \pm 1.1^{\mathrm{n}}$ & $10.3 \pm 2.0^{\mathrm{w}}$ & $10.4 \pm 1.4^{\mathrm{w}}$ \\
\hline & Winnipeg & 0.42 & $10.9 \pm 2.2^{\mathrm{n}}$ & $11.9 \pm 1.4^{\mathrm{w}}$ & $12.2 \pm 1.5^{\mathrm{d}}$ & $13.0 \pm 1.9^{\mathrm{n}}$ & $13.0 \pm 1.5^{\mathrm{w}}$ \\
\hline \multirow{6}{*}{ Semiarid } & Estevan & 0.16 & $10.9 \pm 2.2^{\mathrm{n}}$ & $11.2 \pm 1.1^{\mathrm{w}}$ & $10.3 \pm 1.0^{\mathrm{d}}$ & $11.6 \pm 1.4^{\mathrm{w}}$ & $11.9 \pm 1.7^{\mathrm{w}}$ \\
\hline & Lethbridge & 0.19 & $7.8 \pm 0.9^{\mathrm{d}}$ & $6.8 \pm 1.7^{\mathrm{w}}$ & $6.9 \pm 1.7^{\mathrm{d}}$ & $8.6 \pm 1.6^{\mathrm{w}}$ & $7.8 \pm 2.2^{\mathrm{n}}$ \\
\hline & Medicine Hat & 0.16 & $8.3 \pm 1.2^{\mathrm{d}}$ & $8.1 \pm 1.8^{\mathrm{w}}$ & $7.8 \pm 1.9^{\mathrm{d}}$ & $8.8 \pm 0.9^{w}$ & $8.9 \pm 1.8^{n}$ \\
\hline & Moose Jaw & 0.41 & $9.2 \pm 2.2^{\mathrm{n}}$ & $9.9 \pm 1.3^{\mathrm{w}}$ & $9.2 \pm 1.2^{\mathrm{d}}$ & $10.6 \pm 1.6^{\mathrm{w}}$ & $11.1 \pm 1.7^{\mathrm{w}}$ \\
\hline & Regina & 0.32 & $9.7 \pm 1.9^{\mathrm{n}}$ & $9.9 \pm 1.4^{\mathrm{w}}$ & $9.2 \pm 1.0^{\mathrm{d}}$ & $10.7 \pm 2.0^{\mathrm{w}}$ & $11.2 \pm 2.2^{\mathrm{w}}$ \\
\hline & Saskatoon & 0.47 & $8.8 \pm 1.9^{\mathrm{d}}$ & $9.6 \pm 1.6^{\mathrm{w}}$ & $9.0 \pm 1.0^{\mathrm{d}}$ & $10.2 \pm 1.7^{\mathrm{w}}$ & $11.1 \pm 1.3^{\mathrm{n}}$ \\
\hline
\end{tabular}

$\overline{\mathrm{d}, \mathrm{n}, \mathrm{w}}$ Ecodistricts experiencing dry, normal, and wet growing season based on decadal average of total precipitation compared to 30-year normal precipitation from the start of the growing season (DOY 91) to the peak of foliar expansion period of annual crops (DOY 195).

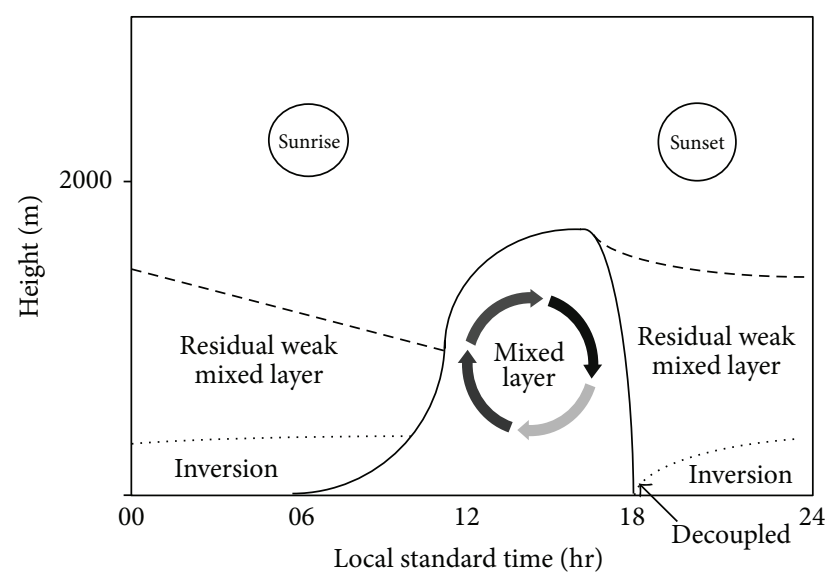

Figure 3: Typical diurnal cycle of mixing-layer depth redrawn based on Oke [7].

both falling and from the surface, is partly responsible for the evening peak in $T_{d}$. Evapotranspiration into an $\mathrm{ABL}$ which is becoming more stable as radiative cooling begins in the evening may also have contributed to the typical evening peak in $T_{d}$. Betts et al. [18] have shown that, on the Canadian Prairies, on a time scale of several days, the relative humidity is highly coupled to precipitation.

Throughout the day during the foliar expansion period, average decadal hourly $T_{d}$ values were higher in the 2000s compared to the 1960s in both climatic zones. However, the increase from the 1960s to the 2000s was neither spatially nor temporally uniform (Table 2). Changes to the decadal average diurnal cycle of $T_{d}$ varied between climatic zones and within the same climatic zone. Wet and dry decades, based on the antecedent precipitation, or the amount of rain from

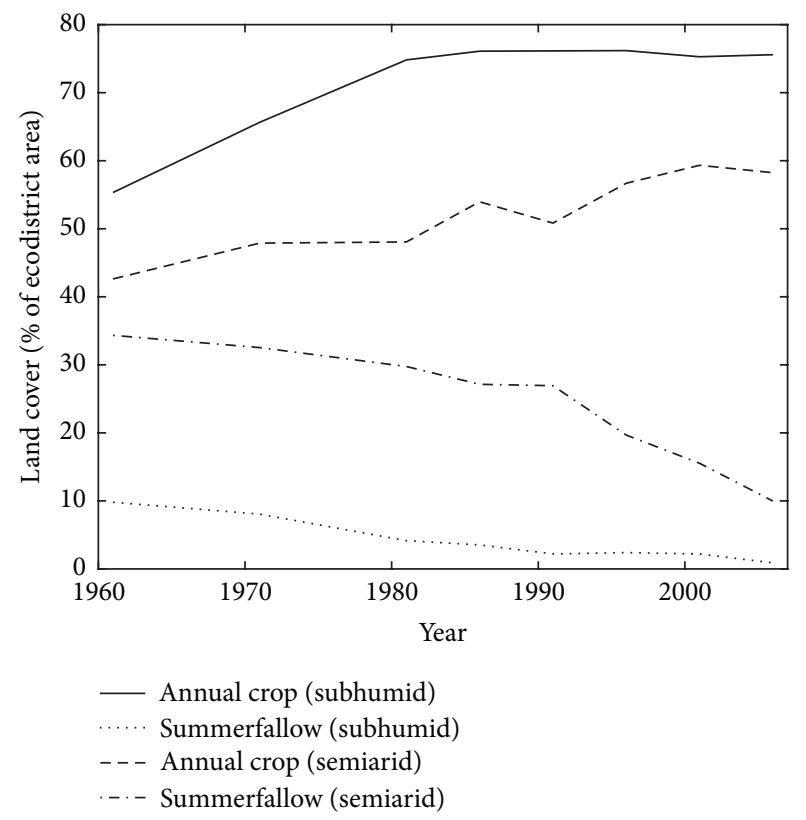

FIGURE 4: Proportion of area covered by annual crops and summerfallow in Ecodistrict 849 (subhumid climatic zone) and Ecodistrict 794 (semiarid climatic zone) from 1961 to 2006.

the start of the growing season through the foliar expansion period, varied from station to station, and the decadal average diurnal cycle of hourly $T_{d}$ values varied with the location and amount of antecedent precipitation in each decade. At a given location, the decadal average diurnal $T_{d}$ cycle's late morning peak was always higher for wetter decades than for drier decades (Figures 2(a) and 2(b) and Table 2). For example, the 1960s was a dry decade for Edmonton and Saskatoon 

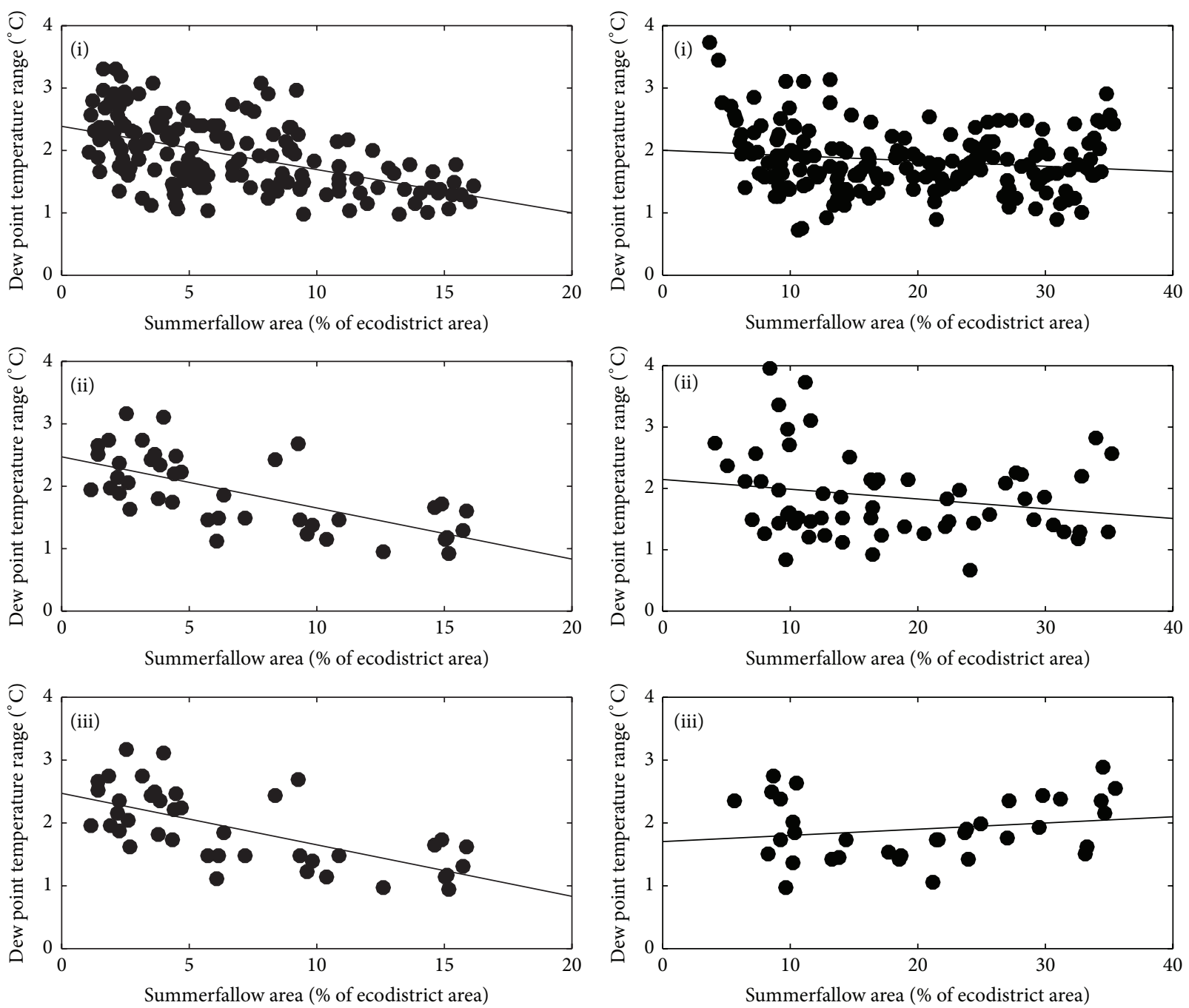

(a)

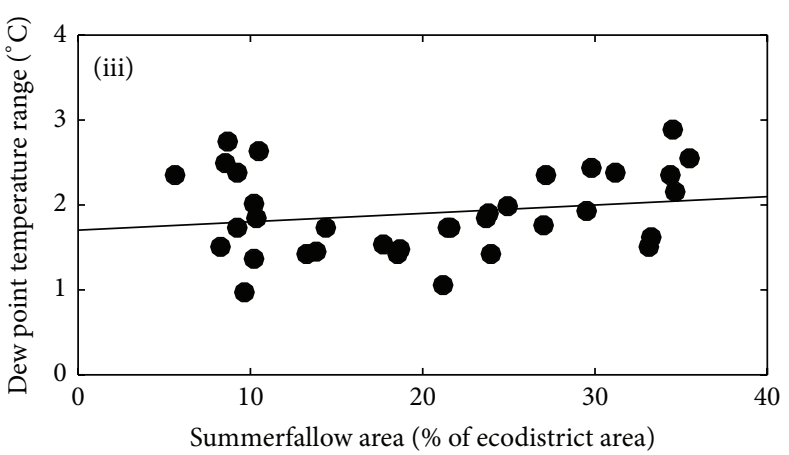

(b)

FIGURE 5: Relationship between the percentage of summerfallow area and seasonal average range of daily dew point temperature (early morning minimum to late morning maximum) from 1961 to 2006 for (a) subhumid and (b) semiarid climatic zone for precipitation regimes, namely, (i) normal years, (ii) wet years, and (iii) dry years.

but a normal decade for Winnipeg and Estevan (Table 2). The driest decade for these latter two stations was the 1980s. Nevertheless, $T_{d}$ values through the average decadal diurnal cycle were lower in the 1980s only for Estevan while $T_{d}$ values through the average decadal diurnal cycle were the lower at Winnipeg in the 1960s. This suggests that, in addition to the antecedent precipitation, the decadal average diurnal $T_{d}$ cycle was also influenced by other factors such as the decrease in summerfallow acreage and the increase in annual crops (Tables 1 and 2). Specifically, ED 849, represented by Winnipeg (in the subhumid climatic zone), had 90,000 ha of summerfallow (10\% of land area) in 1961. This acreage decreased to 8,000 ha $(<1 \%$ of land area) in 2006 (Table 1$)$. At Winnipeg, the decadal average antecedent precipitation in the 1960s was $219.2 \mathrm{~mm}$. This amount is near to the 30 year normal precipitation $(214.7 \mathrm{~mm})$ and suggests that there was generally a normal amount of plant available water in the soil for ET. Thus, one would expect relatively higher $T_{d}$ values at all times of day for the average decadal diurnal cycle in this decade, but they were lower than in the driest decade, the 1980s. This comparison implies that the decadal average diurnal $T_{d}$ cycle was influenced, at least in part, by the coincident decadal average crop acreage.

3.3. Relationship between the Morning Range of Dew Point Temperature and Land Use. The reduction in summerfallow and the increase in annual crop area were greater for the semiarid climatic zone compared to the subhumid climatic zone (Figure 4). Representative weather stations were grouped by antecedent precipitation regime and scatter plots are presented for the subhumid and semiarid climatic zones to determine the relationship between the area of summerfallow and the annual $T_{d r}$, averaged over the foliage expansion period for each year from 1961 to 2006 (Figure 5). In the subhumid climatic zone, a significant negative correlation was observed in all normal, wet, and dry years (Table 3, 
TABLE 3: Summary of the relationships between the annual summerfallow area (\% of total ecodistrict area) and the seasonal average of range of dew point temperatures $\left({ }^{\circ} \mathrm{C}\right)$ from the early morning minimum to the late morning maximum from 1961 to 2006. Bold faced $P$ values show the significant relationships, at the 0.05 level of significance.

\begin{tabular}{lccccc}
\hline Climatic zone & $\begin{array}{c}\text { Precipitation } \\
\text { regime }\end{array}$ & Slope & $R^{2}$ & $P$ value & $\begin{array}{c}\text { Degrees of } \\
\text { freedom }\end{array}$ \\
\hline \multirow{3}{*}{ Subhumid } & Normal & -0.069 & 0.27 & $\mathbf{0 . 0 0 0}$ & 157 \\
& Wet & -0.082 & 0.43 & $\mathbf{0 . 0 0 0}$ & 40 \\
& Dry & -0.062 & 0.22 & $\mathbf{0 . 0 0 9}$ & 28 \\
\hline \multirow{3}{*}{ Semiarid } & Normal & -0.008 & 0.02 & $\mathbf{0 . 0 4 2}$ & 180 \\
& Wet & -0.016 & 0.04 & 0.111 & 60 \\
& Dry & +0.010 & 0.04 & 0.260 & 34 \\
\hline
\end{tabular}

Figure 5(a)). However, in the semiarid climatic zone, the relationship was significant only for the normal years (Table 3, Figure 5(b)(i)). There was a slightly negative relationship $(P=$ 0.11 ) in the wet years but an insignificant positive relationship in the dry years (Table 3 and Figures 5(b)(ii) and 5(b)(iii)). These results indicate that $T_{d r}$ on the Canadian Prairies in the subhumid climatic zone for all years and in the semiarid climatic zone for normal years have been influenced by the replacement of summerfallow by continuous cropping. It is apparent that the replacement of summerfallow by annual cropping affects the atmospheric moisture balance by altering the regional rate of ET as noted by Gameda et al. [10], Shrestha et al. [3], and Haugland and Crawford [26]. From sunrise to late morning, the moisture flux to the atmosphere by ET is related to the annual crop area. Assuming that the contribution from water bodies and perennial crops remains approximately constant from year to year, the increase in annual crop area has resulted in an increased amount of moisture entering the atmosphere during the foliar expansion period.

\section{Conclusions}

This study provides another example of anthropogenic activities leading to regional climate change. We found that the increase in continuous cropping and decrease in summer fallowing from the 1960s to the 2000s have influenced the water cycle process in the Canadian Prairies by increasing $T_{d \text {-mean }}$ and $T_{d r}$ during the foliar expansion period of annual crops. In general, $T_{d \text {-mean }}$ was found to have increased with time and annual $T_{d r}$ was found to be inversely related to the summerfallow acreage which has continually decreased since 1961. This suggests that the adoption of continuous cropping between the 1960s and the 2000s has increased the moisture content of the lower atmosphere during the foliar expansion period of annual crops and hence is contributing to regional climate change. The decadal average diurnal cycle of hourly $T_{d}, T_{d \text {-mean }}$, and annual $T_{d r}$ was also found to be influenced by whether the region was experiencing wet, normal, or dry conditions.

\section{Conflict of Interests}

The authors declare that there is no conflict of interests regarding the publication of this paper.

\section{Acknowledgments}

The authors acknowledge S. Gameda for his advice on this project. They also acknowledge the technical help received from J. Patel and suggestions received from B. Qian and A. Betts. The National Agri-Environmental Health Analysis and Reporting Program of AAFC supported the senior author as an NSERC fellow.

\section{References}

[1] T. N. Chase, R. A. Pielke Sr., T. G. F. Kittel, J. S. Baron, and T. J. Stohlgren, "Potential impacts on colorado rocky mountain weather due to land use changes on the adjacent great plains," Journal of Geophysical Research: Atmospheres, vol. 104, no. 14, pp. 16673-16690, 1999.

[2] R. L. Raddatz, "Evidence for the influence of agriculture on weather and climate through the transformation and management of vegetation: illustrated by examples from the Canadian Prairies," Agricultural and Forest Meteorology, vol. 142, no. 2-4, pp. 186-202, 2007.

[3] B. M. Shrestha, R. L. Raddatz, R. L. Desjardins, and D. E. Worth, "Continuous cropping and moist deep convection on the Canadian prairies," Atmosphere, vol. 3, no. 4, pp. 573-590, 2012.

[4] R. Mahmood, R. A. Pielke, K. G. Hubbard et al., "Land cover changes and their biogeophysical effects on climate," International Journal of Climatology, vol. 34, no. 4, pp. 929-953, 2014.

[5] D. Changnon, M. Sandstrom, and C. Schaffer, "Relating changes in agricultural practices to increasing dew points in extreme Chicago heat waves," Climate Research, vol. 24, no. 3, pp. 243254, 2003.

[6] R. L. Raddatz and J. M. Hanesiak, "Significant summer rainfall in the Canadian Prairie Provinces: modes and mechanisms 2000-2004," International Journal of Climatology, vol. 28, no. 12, pp. 1607-1613, 2008.

[7] T. R. Oke, Boundary Layer Climates, Routledge, London, UK, 2nd edition, 1987.

[8] AAFC, Interpolated Census of Agriculture by Ecodistricts, 2014, http://data.gc.ca/data/en/dataset/58ec1dc1-f225-4290-b6d7a26ad19b528b.

[9] C. A. Campbell, R. P. Zentner, S. Gameda, B. Blomert, and D. D. Wall, "Production of annual crops on the Canadian prairies: trends during 1976-1998," Canadian Journal of Soil Science, vol. 82, no. 1, pp. 45-57, 2002.

[10] S. Gameda, B. Qian, C. A. Campbell, and R. L. Desjardins, "Climatic trends associated with summerfallow in the Canadian Prairies," Agricultural and Forest Meteorology, vol. 142, no. 2-4, pp. 170-185, 2007.

[11] J. Hanesiak, M. Melsness, and R. Raddatz, "Observed and modeled growing-season diurnal precipitable water vapor in south-central Canada," Journal of Applied Meteorology and Climatology, vol. 49, no. 11, pp. 2301-2314, 2010.

[12] K. D. Hage, "Urban-Rural Humidity Differences," Journal of Applied Meteorology, vol. 14, no. 7, pp. 1277-1283, 1975. 
[13] IPCC 2006, "IPCC guidelines for national greenhouse gas inventories," in Agriculture, Forestry and Other Land Use, Intergovernmental Panel on Climate Change, H. S. Eggleston, L. Buendia, K. Miwa, T. Ngara, and K. Tanabe, Eds., National Greenhouse Gas Inventories Programme, Tokyo, Japan, 2006.

[14] Ecoregions Working Group, Ecoclimatic Regions of Canada, First Approximation, Ecological Land Classification Series no. 23, Environment Canada, Ottawa, Canada, 1989.

[15] Soil Classification Working Group, The Canadian System of Soil Classification, Agriculture and Agri-Food, Ottawa, Canada, 3rd edition, 1998.

[16] Y. He, H. Wang, B. Qian, B. McConkey, and R. DePauw, "How early can the seeding dates of spring wheat be under current and future climate in Saskatchewan, Canada?" PLoS ONE, vol. 7, no. 10, Article ID e45153, 2012.

[17] A. K. Betts, R. Desjardins, and D. Worth, "Cloud radiative forcing of the diurnal cycle climate of the Canadian Prairies," Journal of Geophysical Research: Atmospheres, vol. 118, no. 16, pp. 8935-8953, 2013.

[18] A. K. Betts, R. Desjardins, D. Worth, and D. Cerkowniak, "Impact of land use change on the diurnal cycle climate of the Canadian prairies," Journal of Geophysical Research: Atmospheres, vol. 118, no. 21, pp. 11,996-12,011, 2013.

[19] A. K. Betts, R. Desjardins, D. Worth, S. Wang, and J. Li, "Coupling of winter climate transitions to snow and clouds over the Prairies," Journal of Geophysical Research: Atmospheres, vol. 119, no. 3, pp. 1118-1139, 2014.

[20] A. K. Betts, R. Desjardins, D. Worth, and B. Beckage, "Climate coupling between temperature, humidity, precipitation, and cloud cover over the Canadian Prairies," Journal of Geophysical Research D: Atmospheres, vol. 119, no. 23, pp. 13305-13326, 2014.

[21] A. K. Betts, R. Desjardins, A. C. M. Beljaars, and A. Tawfik, "Observational study of land-surface-cloud-atmosphere coupling on daily timescales," Frontiers in Earth Science, vol. 3, article 13, 18 pages, 2015.

[22] L. A. Vincent, W. A. van Wijngaarden, and R. Hopkinson, "Surface temperature and humidity trends in Canada for 19532005," Journal of Climate, vol. 20, no. 20, pp. 5100-5113, 2007.

[23] K. E. Runnalls and T. R. Oke, "Dynamics and controls of the near-surface heat island of Vancouver, British Columbia," Physical Geography, vol. 21, no. 4, pp. 283-304, 2000.

[24] Environment Canada, Documentation for the Digital Archive of Canadian Climatological Data (Surface) Identified By Element, 2014, http://climate.weather.gc.ca/prods_servs/documentation index_e.html.

[25] R. L. Raddatz, "Moisture recycling on the Canadian Prairies for summer droughts and pluvials from 1997 to 2003," Agricultural and Forest Meteorology, vol. 131, no. 1-2, pp. 13-26, 2005.

[26] M. J. Haugland and K. C. Crawford, "The diurnal cycle of dewpoint across Oklahoma's winter wheat belt," in Proceedings of the 13th Symposium on Global Climate Change and Climate Variations, pp. 254-256, American Meteorological Society, Orlando, Fla, USA, 2002. 

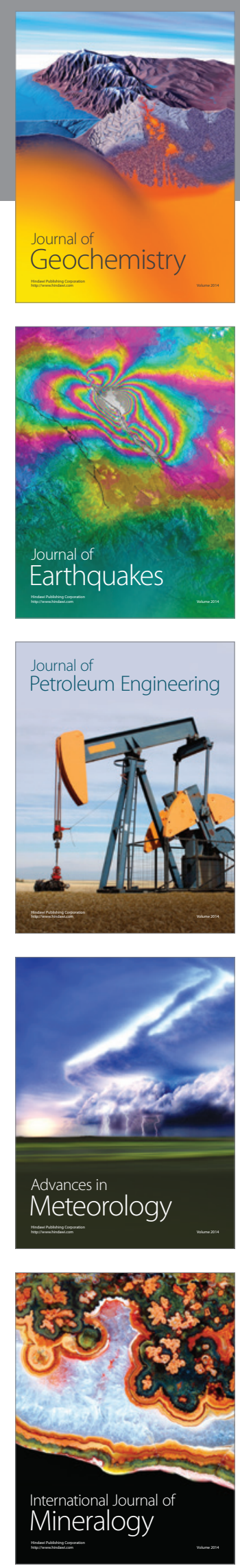
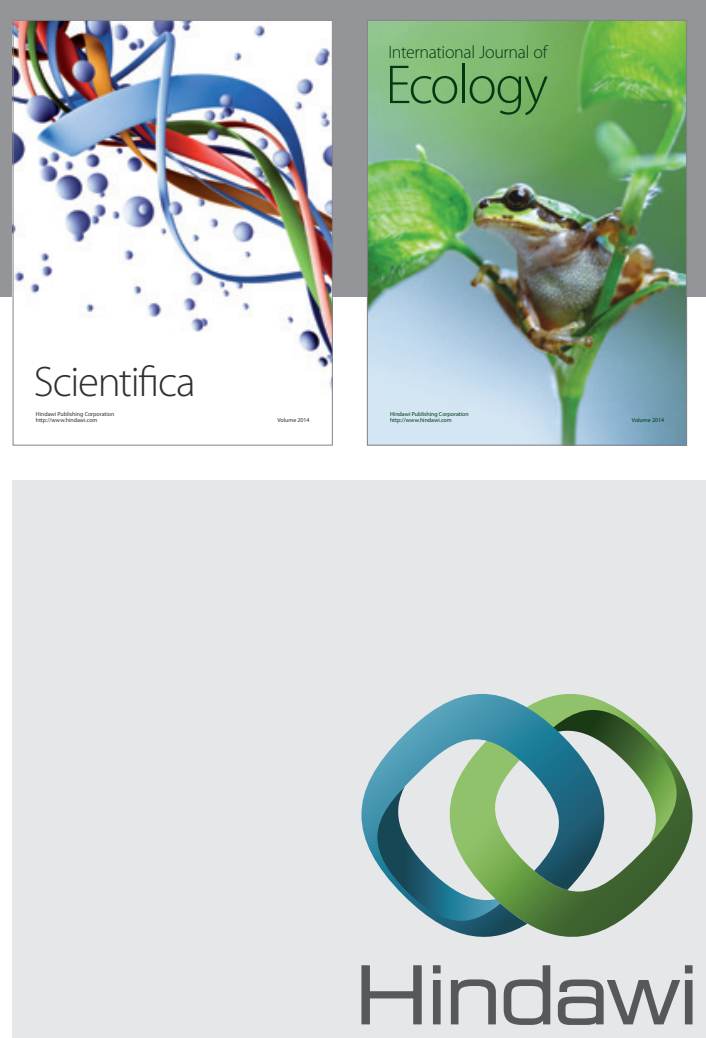

Submit your manuscripts at

http://www.hindawi.com
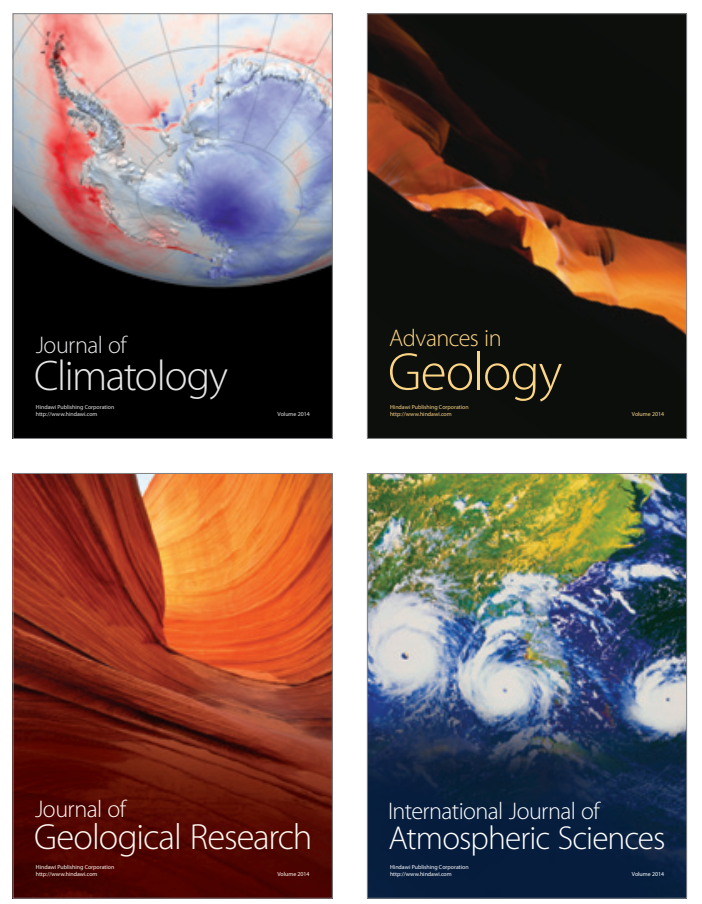

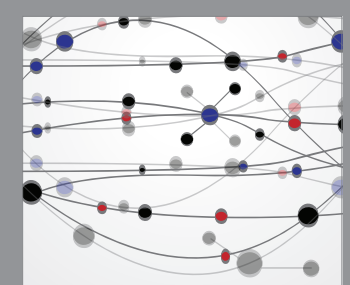

The Scientific

\section{World Journal}
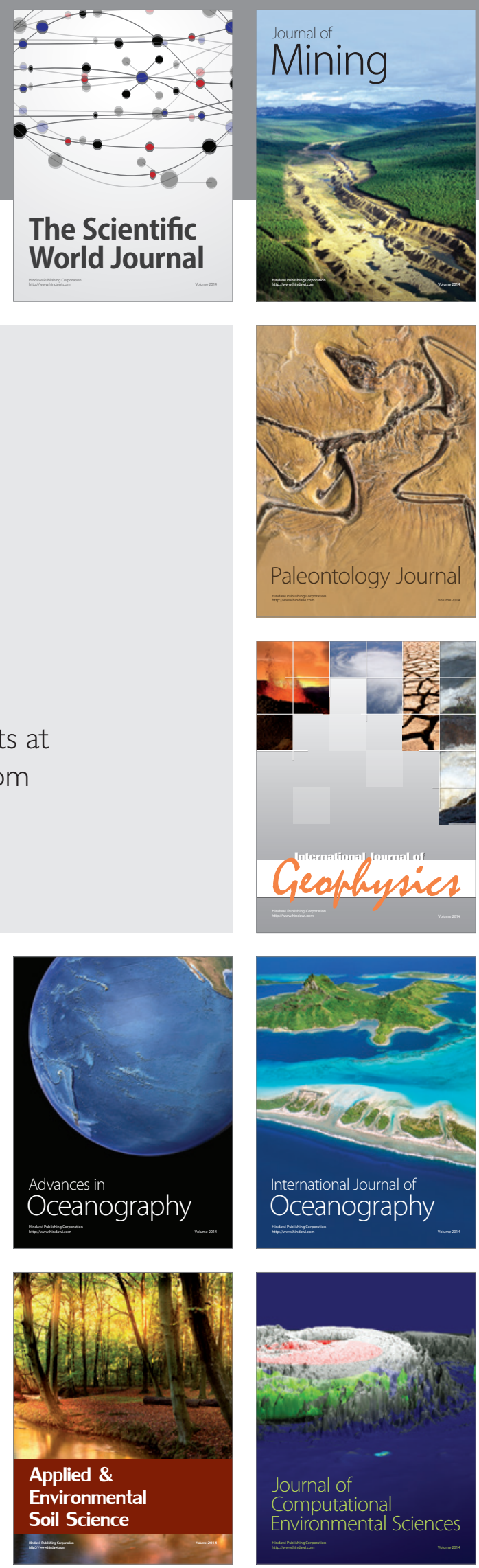